\title{
Relation between Distances, Malodor Perceptions and Respiratory Problems in Cipayung Landfill
}

\author{
Rima Maulida Hidayati, Suyud Warno Utomo, Haryoto Kusnoputranto
}

\begin{abstract}
The waste which enters Cipayung landfill is 800 tons/day and the height of the waste heap reaches 30 meters. This study aims to investigate the perceptions of people living near the landfill regarding respiratory problems and malodor complaints which come from the landfill and to identify the relationship between home distance from landfill with malodor complaints and respiratory problems. This research uses primary data using a questionnaire consisting of 3 parts, including general characteristics of respondents, malodor perceptions, and respiratory problems. The sample is 100 people who live in Hamlet 07, Cipayung Urban Village. All respondents (100\%) smell foul of the landfill, with the majority saying that the smell disturbs daily activities (70\%) and causes unhealthy effects (75\%). Majority of respondents $(81 \%)$ had suffered respiratory problems during living near the landfill. And the most frequent symptom of respiratory problems in the last 2 weeks was coughing (25\%). There are significancies of relation between distances and malodor perceptions (p-value 0.015), and relation between distances and respiratory problems $(0.038)$ If malodor coming from the Cipayung landfill left untreated it will have more serious long-term effects. So it needs amelioration of processing system and other efforts by the stakeholders in order to decrease the risk of health and environment problems caused by H2S from Cipayung Landfill.
\end{abstract}

Keywords: Community perception, Malodor, Respiratory problems, Hydrogen Sulfide

\section{INTRODUCTION}

Globally there are around 7 million deaths caused by air pollution. World Health Organization (WHO) report in 2008 approximately 1.3 million deaths were related to ambient air pollution in globally. That number then rose almost 3 times to 3.7 million in 2012. Air pollution affects most organs and systems of the human body, respiratory system, cardiovascular system, digestive system, nervous system, and urinary system [1]. Air pollution can be formed from industrial activities or occurs naturally, one of that is the waste decomposition that produces hydrogen sulfide gas. Hydrogen sulfide $\left(\mathrm{H}_{2} \mathrm{~S}\right)$ is a noncolor, flammable, highly toxic gas and has a specific characteristic that smells like

Revised Manuscript Received on January 2, 2020.

* Correspondence Author

Rima Maulida Hidayati*, Master Program of Environmentah Health, Faculty of Public Health, Universitas Indonesia. Email: rimamaulida78@gmail.com

Suyud Warno Utomo, Department of Environmental Health, Faculty of Public Health and School of Environmental Science, Environmental Studies Program, Universitas Indonesia. Email: suyud.ui@ui.ac.id

Haryoto Kusnoputranto, Department of Environmental Health, Faculty of Public Health-Universitas Indonesia. Email: haryoto_k@yahoo.com

rotten eggs. Humans can be exposed to $\mathrm{H}_{2} \mathrm{~S}$ mainly through inhalation and can be quickly absorbed by the lungs. Exposure to $\mathrm{H}_{2} \mathrm{~S}$ at low concentration can cause irritation of the throat and eyes, coughing, dizziness, and neurological symptoms such as incoordination, hallucinations, and reduced memory [2].

The respiratory tract and nervous system are the most sensitive organs when exposed to $\mathrm{H}_{2} \mathrm{~S}$ exposure. $\mathrm{H}_{2} \mathrm{~S}$ at high concentrations can cause someone to lose their ability to smell, so it is wrong to think that $\mathrm{H}_{2} \mathrm{~S}$ is no longer available even though it still exists. This can increase the risk of exposure to air levels which can cause serious health effects [2]. Most health effects are respiratory disorders. Complaints of breathing can be coughing, coughing up phlegm, breathing sounds/wheezing, shortness of breath, breathing sound/wheezing accompanied by shortness of breath, chest pain, flu and coughing with flu [3].

Landfills in the decomposition process can produce harmful gases that can caused health problems. One of the gases produced at the landfill is hydrogen sulfide [4]. Peoples living near the landfill are directly exposing to volatile H2S compounds. Long-term exposure of $\mathrm{H} 2 \mathrm{~S}$ is associated with potential health risks, such as irritation of respiratory system, cancer and damage to the central nervous system [5]. Cipayung Landfill which began operating in 1984, is located in Cipayung Village, Depok City. Cipayung Landfill is a waste collection place originating from 11 subdistricts in Depok City with an area of 10.8 hectares. The area of the Cipayung landfill is categorized as overload with the amount of garbage entering 800 tons per day and will continue to increase with the height of 30 meters of waste generated [6]. The air quality around Cipayung Landfill for $\mathrm{H}_{2} \mathrm{~S}$ parameters is $0.14 \mathrm{mg} / \mathrm{m} 3$ (converted to $0.1 \mathrm{ppm}$ ) which means it passes the odor threshold value based on the Decree of the Minister of Environment of the Republic of Indonesia Number 50 of 1996 which is 0.02 ppm [7]. Based on preliminary studies that have been conducted by researchers with direct observation and interviews with the people who live around the Cipayung Landfill, 15 out of 15 people who have lived more than 15 years mentioned having experienced respiratory complaints such as coughing, chest pain, and most often was sick throat due to the foul odor of landfill. Based on observations obtained smells like rotten eggs detected strong enough from a distance of 1 kilometer and smelled stronger when the wind blew. 


\section{MATERIALS AND METHODS}

\section{A. Data sources and Study Population}

This study uses primary data derived from data collected using a questionnaire. The population in this study were all residents of hamlet 07, Cipayung Urban Village, which is the closest settlement to the landfill. Based on the sample size, 100 people became the study samples. The inclusion criteria determined are people aged $\geq 18$ years based on anthropometric uniformity and duration of living close the landfill $\geq 9$ years based on the results of $\mathrm{H}_{2} \mathrm{~S}$ measurements around the Cipayung Landfill in 2010 carried out by the Depok City Environment Agency.

\section{B. Measurements and Data Analysis}

Measurements were made using a questionnaire divided into 3 parts, consisting of the characteristics of respondents (age, sex, length of stay, and distance of the house from the landfill as measured by researchers using the Google Maps), complaints of odor from the landfill, and respiratory complaints (questions regarding symptoms of respiratory problems refer to the American Thoracic Society). Descriptive statistics generated for the questionnaire, means, minimum-maximum and frequencies used to describe variables. Chi square test used for identify relation between distance from landfill with malodor complaints and respiratory promblems.

\section{RESULTS AND DISCUSSIONS}

\section{A. General Characteristic of People Living Close Landfill}

Table I shows that majority of responden in this study were female. In terms of age group, the 18-45 years old range was the highest represented with $68 \%$ followed by $>45$ years $(32 \%)$. Majority of duration of time living close the landfill was $>20$ years $(61 \%)$. Most of the respondents live with a distance of $<300$ meters from the landfill which is $76 \%$.

Tabel I. General Characteristic of Respondents

\begin{tabular}{|c|c|c|c|c|}
\hline & Number & Percentage $(\%)$ & Min-Max & Mean \\
\hline \multicolumn{5}{|l|}{ Gender } \\
\hline $\begin{array}{c}\text { Male } \\
\text { Female }\end{array}$ & $\begin{array}{l}23 \\
77\end{array}$ & $\begin{array}{l}23 \\
77\end{array}$ & - & - \\
\hline Total & 100 & 100 & & \\
\hline \multicolumn{5}{|l|}{ Age } \\
\hline $\begin{array}{c}18-45 \text { years } \\
>45 \text { years }\end{array}$ & $\begin{array}{l}68 \\
32\end{array}$ & $\begin{array}{l}68 \\
32\end{array}$ & 19-74 years & $\begin{array}{l}41.26 \\
\text { years }\end{array}$ \\
\hline Total & 100 & 100 & & \\
\hline \multicolumn{5}{|c|}{ Duration of time living close the landfill } \\
\hline $\begin{array}{l}9-20 \text { years } \\
>20 \text { years }\end{array}$ & $\begin{array}{l}39 \\
61\end{array}$ & $\begin{array}{l}39 \\
61\end{array}$ & 9-74 years & $\begin{array}{l}28.62 \\
\text { years }\end{array}$ \\
\hline Total & 100 & 100 & & \\
\hline \multicolumn{5}{|c|}{ Distances from landfill } \\
\hline $\begin{array}{l}<300 \text { meters } \\
\geq 300 \text { meters }\end{array}$ & $\begin{array}{l}76 \\
24\end{array}$ & $\begin{array}{l}76 \\
24\end{array}$ & $120-600$ meters & $\begin{array}{l}275.0 \\
\text { meters }\end{array}$ \\
\hline Total & 100 & 100 & & \\
\hline
\end{tabular}

The existence of a landfill in an area can have an impact on the peoples who live around it [8]. Therefore, the

distance between the landfill site and the nearest residential area is a crucial thing. The majority of respondents in the study were respondents whose home distance from the landfill was less than 300 meters with the nearest distance of only 120 meters. This distance is not by the recommended distance between the landfill site and the residential area. Some recommended distance between the landfill site and the nearest residential area; 1) based on the Regulation of the Minister of Public Works of the Republic of Indonesia the recommended distance is at least $1 \mathrm{~km} \mathrm{[9],} \mathrm{2)}$ International Solid Waste Association the recommended minimum distance is 500 meters [10], 3) Standards and Regulations of British Columbia in Canada recommend a distance of at least 300 meters [11]. The recommended distance is a consideration for the exposure of the community to pollution caused by the landfill (leachate pollution, air pollution, odor, disease vector spread). Previous research found that residential houses with short distances $(<124.94$ meters) with landfill have higher air pollutant yields compared to those far away [12]. In line with the research result by Singga on scavengers at the Kupang Alak landfill found an association between the distance of the residence of the scavengers and health problems experienced by scavengers [13].

\section{B. Malodor Perceptions in People Living Close Cipayung Landfill}

Fig. 1 shows that the smell like rotten eggs (malodor) is most often smelled by people living close landfills during afternoon which is $56 \%$.

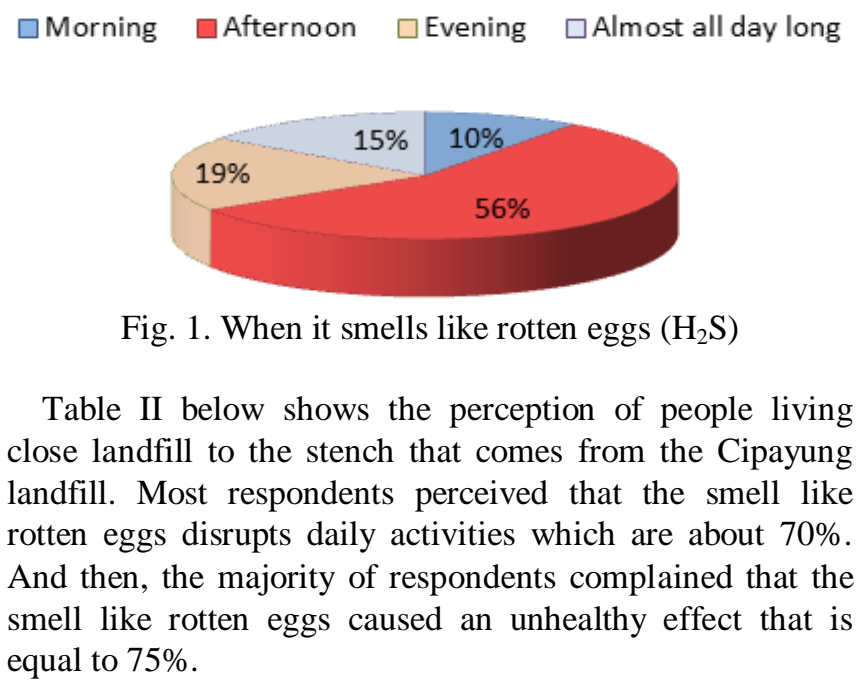

Table II. Perception of malodor (smells like rotten eggs) coming from the landfill

\begin{tabular}{|l|c|c|c|c|c|c|}
\hline \multirow{2}{*}{} & \multicolumn{2}{|c|}{ Yes } & \multicolumn{2}{c|}{ No } & \multicolumn{2}{c|}{ Total } \\
\cline { 2 - 7 } & $\mathrm{N}$ & $\%$ & $\mathrm{~N}$ & $\%$ & $\mathrm{~N}$ & $\%$ \\
\hline $\begin{array}{l}\text { The smell } \\
\text { disturbs daily } \\
\text { activities }\end{array}$ & 70 & 70 & 30 & 30 & 100 & 100 \\
\hline $\begin{array}{l}\text { The smell } \\
\text { has an } \\
\text { unhealthy } \\
\text { effect }\end{array}$ & 75 & 75 & 25 & 25 & 100 & 100 \\
\hline
\end{tabular}


Cipayung landfill which has established for more than 35 years still operates with an open dumping system. Open dumping systems that are used can have bad impacts on both the environment and human health, including causing air contamination and odor pollutions [14]. This is worsened by the situation where the landfill waste heap passed the maximum capacity, which reached 30 meters from the ground.

Based on the study result, all respondents $(100 \%)$ claimed to have smelled like rotten eggs originating from landfill. Even so, respondents who consider the odor to disturb with their daily activities are $70 \%$ and consider the odor to have an unhealthy effect on them by $75 \%$. This is in line with previous research of people who live close to landfills. It is found that $75 \%$ strongly agree living close to a landfill raises concern for them, with the majority of reasons worrying, is due to health [15]. And then, previous research conducted by Sakawi et al. showed that $83.7 \%$ of respondents living close to landfill felt the bad odor had affected the tranquility and quality of life, also showed that the bad odor is disruptive to the everyday life of them [16].

\section{Respiratory Problems in People Living Close Cipayung Landfill}

Fig. 2 shows that almost all respondents stated that they had experienced respiratory problems during living near Cipayung Landfill (81\%). Symptoms of respiratory problems that are often complained of in the last 2 weeks are cough by $25 \%$, can be seen in Fig. 3 .
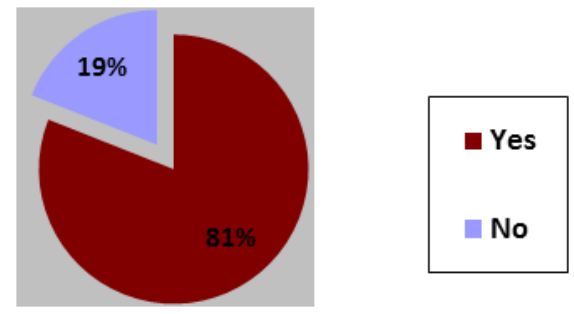

Fig. 2. Have experienced respiratory problems (shortness of breath, chest pain, coughing, coughing with phlegm) during living close the Cipayung Landfill

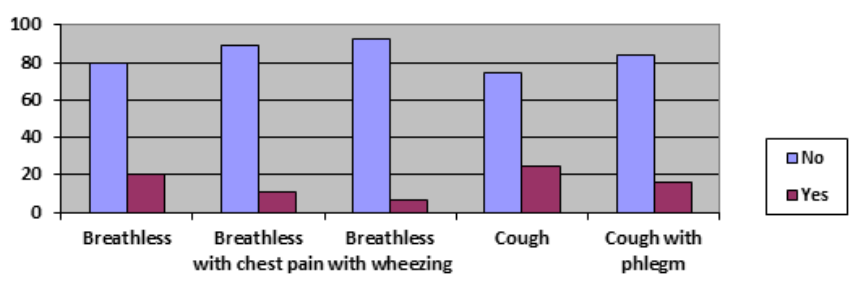

Fig. 3. Respiratory problems that have been experienced in the last 2 weeks by peoples who live close the Cipayung landfill

One of the impacts arising from the presence of landfill is the production of air pollutants or gases, one of which is Hydrogen Sulfide (H2S). H2S quickly enters the body through inhalation and the health effects that often detect are respiratory problem [2]. Based on this study result, it was found that the majority of respondents (81\%) stated that they had experienced breathing problems while living near the Cipayung landfill with symptoms including shortness of breath, coughing, coughing with phlegm, shortness of breath accompanied by chest pain, and breathing sounds.

\section{Relation Between Distances from Landfill and Malodor Perceptions}

Table III below show the result of relation between distance of respondent house frome landfill with perception of bad odor cause unhealthy effect. From 100 total respondents, there are $52(52 \%)$ respondents who were $<300$ meters from the landfill stated that bad odor had an unhealthy effect on them. Based on X2 Square test, the p-value is 0.015, which means that there is an association between the distance from the landfill and respondent perception about bad odor cause an unhealthy effect (CI 0.02-1.11).

Table III. Crosstabulation between distances from landfill and malodor perception

\begin{tabular}{|l|c|c|c|c|}
\hline \multirow{2}{*}{$\begin{array}{c}\text { Distances } \\
\text { from landfill }\end{array}$} & \multicolumn{2}{|c|}{$\begin{array}{c}\text { Bad Odor Cause } \\
\text { Unhealthy Effect }\end{array}$} & \multirow{2}{*}{ Total } & \multirow{2}{*}{ Significance } \\
\cline { 2 - 4 } & $\begin{array}{c}\text { Yes } \\
\mathbf{n}(\%)\end{array}$ & $\begin{array}{c}\text { No } \\
\mathbf{n}(\%)\end{array}$ & & \\
\hline$<300$ meters & $\begin{array}{c}52 \\
(52 \%)\end{array}$ & $\begin{array}{c}24 \\
(24 \%)\end{array}$ & $\begin{array}{c}76 \\
(76 \%)\end{array}$ & \multirow{2}{*}{0.015} \\
\hline$\geq 300$ meters & $\begin{array}{c}23 \\
(23 \%)\end{array}$ & $\begin{array}{c}1 \\
(1 \%)\end{array}$ & $\begin{array}{c}24 \\
(24 \%)\end{array}$ & \multirow{2}{*}{\begin{tabular}{|}
100 \\
$(100 \%)$
\end{tabular}} \\
\hline Total & $\begin{array}{c}75 \\
(75 \%)\end{array}$ & $\begin{array}{c}25 \%) \\
(25 \%)\end{array}$ & \\
\hline
\end{tabular}

Odor complaints may also be associated with Hydrogen Sulfide (H2S) that produced from waste material in landfill. $\mathrm{H} 2 \mathrm{~S}$ at low concentrations can made irritation of eye and respiratory tract mucous membranes. High concentrations of $\mathrm{H} 2 \mathrm{~S}$ can cause more serious health problems such as depression of the central nervous system, loss of consciousness and respiratory paralysis [17]. Previous study of $\mathrm{Njoku}$ found that majority of respondents (78\%) lived nearer to the landfill site (100-500 meters) showed high contamination of air quality from bad odors that come from the landfill [18]. Health problems reported by respondents living closer to the landfill (irritation of the eye, flu, and body weakness). The same survey results by Sakawi et al. showed that $80.5 \%$ of respondents who living near the landfill stated bad odor coming from the landfill associated with their health effects [16].

\section{E. Relation Between Distances from Landfill and Respiratory Problems}

Table IV show the result study about relation between distances from landfill and respiratory problems. There are $58 \%$ of respondents who were $<300$ meters from landfill, have suffered respiratory problems. Based on data analysis, the p-value is 0.038 , which means that there is an association between the distance from the landfill and respiratory problems (CI 0.01-0.74). Reported from the previous study show that the residents who live close to the landfill experience breathing disorder while living near the landfill [18]. Then the results of a cohort study also showed an association between living close to a landfill and damage to the respiratory system, and symptoms of respiratory disorders among 
residents living near landfills [19]. And then, a previous study by Putri conducted on workers at the Super Depo Sutorejo landfill showed that $76.2 \%$ of workers had experienced respiratory complaints while working at the landfill [20].

Table IV Crosstabulation between distances from landfill with respiratory problems

\begin{tabular}{|c|c|c|c|c|}
\hline \multirow{2}{*}{$\begin{array}{l}\text { Distances } \\
\text { from } \\
\text { landfill }\end{array}$} & \multicolumn{2}{|c|}{$\begin{array}{c}\text { Respiratory } \\
\text { Problems }\end{array}$} & \multirow[b]{2}{*}{ Total } & \multirow[b]{2}{*}{ Significance } \\
\hline & $\begin{array}{c}\text { Have } \\
\text { Suffered } \\
\text { n }(\%)\end{array}$ & $\begin{array}{l}\text { Never } \\
\text { n }(\%)\end{array}$ & & \\
\hline $\begin{array}{l}<300 \\
\text { meters }\end{array}$ & $\begin{array}{c}58 \\
(58 \%)\end{array}$ & $\begin{array}{c}18 \\
(18 \%)\end{array}$ & $\begin{array}{c}76 \\
(76 \%)\end{array}$ & \multirow{3}{*}{0.038} \\
\hline $\begin{array}{l}\geq 300 \\
\text { meters }\end{array}$ & $\begin{array}{c}23 \\
(23 \%)\end{array}$ & $\begin{array}{c}1 \\
(1 \%)\end{array}$ & $\begin{array}{c}24 \\
(24 \%)\end{array}$ & \\
\hline Total & $\begin{array}{c}71 \\
(71 \%)\end{array}$ & $\begin{array}{c}19 \\
(25 \%)\end{array}$ & $\begin{array}{c}100 \\
(100 \%)\end{array}$ & \\
\hline
\end{tabular}

\section{CONCLUSION}

This study is an important and early effort to understand the issues related to respiratory problems and malodor that emanate from Cipayung landfill. The results of this study that have been carried out show that the smell like rotten eggs, namely $\mathrm{H} 2 \mathrm{~S}$ from the waste generation in the Cipayung Landfill, causes an unhealthy impact and disrupts their daily activities. Besides that, the bad odor also causes respiratory complaints in the population who live near the landfill. With this research, it is expected that the responsible stakeholders can make a comprehensive effort, including repairs, supervision and monitoring to reduce the health and environmental impacts caused by $\mathrm{H} 2 \mathrm{~S}$ originating from the landfill.

\section{ACKNOWLEDGEMENT}

The researcher is grateful and would like thank Department of Environmental Health, Public Health Faculty, Universitas Indonesia.

\section{REFERENCES}

1. Jiang, Mei \& Feng. Air pollution and chronic airway diseases: what should people know and do? Journal of Thoracic Disease 2016; 8(1): E31-E40.

2. Agency for Toxic Substances and Disease Registry. Toxicological profile for hydrogen sulfide and carbonyl sulfide. Atlanta, Georgia: Agency for Toxic Substances and Disease Registry, Public Health Service, US. Department of Health and Human Services. 2016.

3. American Thoracic Society. Recommended respiratory disease questionnaires for usewith adults and children in epidemiological research. 1976.

4. Dwicahyono. Analysis of $\mathrm{NH} 3$ content, individual characteristics and respiratory respiratory complaints in benowo garbage land and nonscavengers around benowo garbage land surabaya. Jurnal Kesehatan Lingkungan 2017; 9(2): 135-144.]

5. Wu, C., et al. Assessment of the health risks and odor concentration of volatile compounds from a municipal solid waste landfill in China. Chemosphere 2018; 202; 1-8

6. Depok City Cleaning and Gardening Service. 2018. https://www.depok.go.id/tag/dkp

7. Depok City Environmental Agency. Depok City Environmental Agency Document Report. 2010.

8. Sabela, S. Risk of health disorders to communities in the vicinity of tanjungrejo garbage district garbage landfill. 2014. Available from https://lib.unnes.ac.id/20246/

9. Regulation of the Minister of Public Works of the Republic of Indonesia in 2013. Implementation of solid waste infrastructure and facilities in handling household waste and trash of similar household waste. 2013

10. International Solid Waste Association. Guidelines for design and operation of municipal solid waste landfills in tropical climates. 2013. Available from https://www.iswa.org/home/news/newsdetail/browse/43/article/new-publication-guidelines-for-the-designand-operation-of-municipal-solid-waste-landfills-in-tropi/109/

11. Derakhshandeh, M. \& Beydokhti, T. T. Management of landfill locating of urban waste. european online journal of natural and social sciences; Special Issue on Environmental, Agricultural, and Energy Science 2014; 3(3).

12. Saepudin \& Amalia. Distance houses to final spot waste, physical house quality toward levels of methane (ch4) in the house in kelurahan batulayang north pontianak subdistrict, pontianak city. Buletin Penelitian Sistem Kesehatan 2016; 19(4): 243-249.

13. Singga, S. Health problems of scavengers at the alak landfill, kupang city. Jurnal Media Kesehatan Masyarakat Indonesia 2014; 30-35.

14. Ferronato, N., \& Torretta, V. Waste mismanagement in developing countries: a review of global issues. International Journal of Environmental Research and Public Health 2019; 16, 1060

15. Drumm, A. C. A study of the health effects of living in close proximity to a landfill and the public perception of landfills. 2006. Available from:

http://mural.maynoothuniversity.ie/5057/1/Aoife_Catriona_Drumm_20 140620142635.pdf

16. Sakawi et al. Community perception of odor pollution from the landfill. Research Journal of Environmental and Earth Sciences 2011; 3(2) 142-145.

17. Health Protection Agency. Impact on health of emissions from landfill site, advice from the Health Protection Agency. 2011. Available from: https://assets.publishing.service.gov.uk/government/uploads/system/up loads/attachment_data/file/334356/RCE18_for_website_with_security. pdf

18. Njoku, P.,O. Health and environmental risks of residents living close to a landfill: a case study of thohoyandou landfill, limpopo province, south africa. International Journal of Environmental Research and Public Health 2019; 16, 2125

19. Mataloni, F., et al. Morbidity and mortality of people who liveclose to municipal waste landfills: a multisitecohort study. International Journal of Epidemiology 2016; 806-815.

20. Putri, G. L. Hydrogen sulfide level and respiratory complaints of officer in garbage management super depo sutorejo surabaya. Jurnal Kesehatan Lingkungan 2018; 10(2): 211-219

\section{AUTHORS PROFILE}



Rima Maulida Hidayati, Education Details: Master Program of Environmental Health, Faculty of Public Health, Universitas Indonesia (2018 - 2020), Bachelor of Nursing; Faculty of Nursing, University of Riau, Indonesia (2013 - 2017), Islamic High School 2 Pekanbaru, Indonesia (2010 - 2013), Islamic Middle School Bukit Batu, Riau, Indonesia (2007 - 2010), Elementry School 1 Sungai Pakning, Riau, Indonesia (2001 - 2007). Publication: The Correlation Between Duration of Laptop Usage and Computer Vision Syndrome's Symptoms of Nursing Students in Riau University (Jurnal Ners Indonesia, 2017), The Impact of Hydrogen Sulfide Exposure to Respiratory Symptoms In The People Living Around The Cipayung Landfill Depok West Java Indonesia in 2019 (THESIS, 2019)

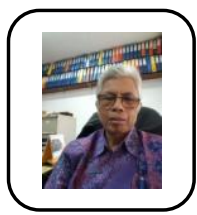

Suyud Warno Utomo, Lecturer at Departement of Environment Health and School of Environmental Science, Universitas Indonesia, Education Details: Drs (Universitas Gadjah Mada), M. Si (Universitas Indonesia, Dr (Universitas Negeri Jakarta). Publications: The Correlation between Age, Gender, and Nutritional Status with Pesticide Poisoning at Holtikultura Farmes in Cikajang Sub-District, Garut District, West Java (Indian Journal of Public Health Research \& Development, Volume 9 /No 11/2018), Knowledge, Attitude, and Behavior of Farmers in the Use of Pesticides with Health Complaints in Cikandang Village, Cikajang Sub-District, Garut Regency 2017 (Indian Journal of Public Health Research \& Development, 2018) Identification of Organophosphate Pesticides Reside on Tomatos, potatoes, Chilis, Cubes, Carrots, Soil and water in Garut, Indonesia In 2017 (Australian Journal of Basic and Applied Sciences, 12(3) March /2018), Health Risk Analysis of Nickel and Lead Exposure in Drinking Water at Kawasi Village, Obi Island, South Halmahera District, 2015 
(Asian Journal of Applied Sciences, Volume 6 /No 01 /2018),

A Climate Risk Assesment of Clean Water Supply in an Urban Area: A Case Study of South Tangerang City, Indonesia (IOP Conference Series: Earth and Environmental Science, 2018), Study on Effectiveness Recharge Wells for Water Conservation Land and Reduction of Flood (Case Study Recharge Well in Eat Jakarta and South Jakarta) (Australian Journal of Basic and Applied Sciences, 11(11) August /2017), Mangrove Ecosystem Viability of Muara Angke Wildlife Reserve (SMMA) towards the Pollution Pressure (Australian Journal of Basic and Applied Sciences, 11(13) October 12017), Health Safety Security and Environment (HSE) Perception at the Ferry Port Terminal: A Case Study at Merak, Banten Province, Indonesia (Asian Journal of Applied Sciences, Volume 5/No 1/2017), Health Risk Analysis Due to Vegetable Consumption of Cabbage, Carrot, and Chili which Contain Organophosphate Pesticides Residue to the Horticulture Farmers in District of Cikajang, Garut, West Java, Indonesia 2017 (Asian Journal of Applied Sciences, Volume 5/No 5/ 2017), Diversity and Potential of Carbon Content From Green Open Space at Soekarno Hatta International Airport (Australian Journal of Basic and Applied Sciences, 11(13) October/2017)



Haryoto Kusnoputranto, Lecturer at Departement of Environmental Health, Faculty of Public Health, Universitas Indonesia. Education Details: dr, SKM (Universitas Indonesia), Dr.PH (University of Pittsburgh-USA). Publications: Environmental health risk due to exposure to lead in batteries smelter industry- Cinangka Village, Bogor, Indonesia (January 2018 Indian Journal of Public Health Research and Development 9(12):691), Human Dimension Plays a Role in Realizing The Health of the Urban Dwelling, Jakarta,Indonesia (Indian Journal of Public Helath Research and Development 9(12) 2018), Improvement efforts of hazardous waste management implementation in Karimun Regency fabrication yard, Indonesia (November 2018 Indian Journal of Public Health Research and Development 9(11):293), Changing rural communities behavior towards safe water and improved sanitation in Indonesia (January 2018, Indian Journal of Public Health Research and Development 9(10):527), Developing thermal comfort model through regional budget expenditure analysis towards low energy consumption in public building facility (case object: government building in north and south of Jakarta) (E3S Web Conf.Volume 74, 2018 International Conference Series on Life Cycle Assessment: Life Cycle Assessment as A Metric to Achieve Sustainable Development Goals (ICSoLCA 2018), The Role of Alpha-1 Antitrypsin Enzyme On Pulmonary Dysfunction Due to Exposure to NO2(Research Journal of Applied Sciences 13 (4):229-234, 2018. ISSN; 1815-932X. Medwell Journals, 2018), Malondialdehyde (MDA) as Biomarkers of Oxidative Stress to PM2.5 Exposure at Junior High School Students in Bandung City, West Java, Indonesia (Pollution Research. Vol. 37 (2) : 287-294: 2018), Identification of Organophosphate Pesticide Reside on Tomatoes, Potatoes, Chilis, Cubes, Carrots, Soil,and Water in Garut, Indonesia in 2017 (Australian Journal of Basic and Applied Sciences, 2018 March; 12(3): pages 31-34), Health Risk Analysis of Nickel and Lead Exposure in Drinking Water at Kawasi Village, Obi Island, South Halmahera District, 2015 (Asian Journal of Applied Sciences. Vol 06 Issue 01, February 2018), Health Risk Analysis Due to Vegetable Consumption of Cabbage, Carrot and Chili which Contain Organophosphate Pesticides Residue to the Horticulture Farmers in District of Cikajang, Garut, West Java, Indonesia 2017 (Asian Journal of Applied Sciences, Vol 05 - Issue 05, October 2017) 